\title{
Emergency embolization after resection of a laryngeal Schwannoma
}

\section{Embolização de urgência após ressecção de schwanoma de laringe}

\author{
Fábio Augusto Cypreste Oliveira ${ }^{1,2,3}$, Carlos Eduardo de Sousa Amorelli ${ }^{1,2,3}$, Fábio Lemos Campedelli, ${ }^{1,2,3}$, \\ Werther Sales 4 , Maria Cunha Ribeiro Amorelli4, Juliana Caetano Barreto5, \\ Mariana Caetano Barreto 5 , Philippe Moreira da Silva ${ }^{4}$
}

\begin{abstract}
Schwannoma is a rare cause of benign tumors of the larynx. The first-choice treatment is surgical resection. The objective of this paper is to report on a rare case of a young female patient who suffered severe intraoperative hemorrhaging during surgical resection of a laryngeal Schwannoma and needed emergency embolization.
\end{abstract}

Keywords: therapeutic embolization; schwannoma; larynx.

\section{Resumo}

O schwanoma representa etiologia rara de tumor benigno de laringe, tendo como principal tratamento a ressecção cirúrgica. O objetivo deste trabalho é relatar um caso raro de paciente jovem submetido à ressecção cirúrgica de schwanoma laríngeo, evoluindo, no transperatório, para complicação hemorrágica grave e necessitando de embolização de urgência.

Palavras-chave: embolização terapêutica; schwanoma; laringe. 


\section{INTRODUCTION}

Schwannomas are benign tumors that typically grow slowly, are encapsulated and have extensive vascularization. They get their name from the fact that they originate in the Schwann cells of motor, sensory or cranial nerves, but do not contain nervous elements. The most common site is the side of the neck, originating in the cervical nerve roots and the cervical sympathetic trunk ${ }^{1}$. They are rarely found in the larynx and there are only sporadic reports of this presentation in the literature. Laryngeal Schwannomas account for less than $0.5 \%$ benign tumors of the larynx and the first choice treatment is surgery, despite the fact that degeneration to malignancy is extremely rare $^{2-7}$.

\section{CASE DESCRIPTION}

The patient was a 29 -year-old female (S.R.X.) with a history of progressive solids dysphagia and a sensation of pharyngeal bolus. After initial evaluation by the otorhinolaryngology team, videolaryngoscopy and computed tomography of the neck identified an encapsulated solid tumor of the larynx with an intimate relationship with the right external and internal carotid arteries (Figure 1).

The patient was operated on by the otorhinolaryngology team under general anesthetic. A transoral approach was used to achieve total resection of the tumor. However, after removal of the tumor, the patient exhibited massive and persistent

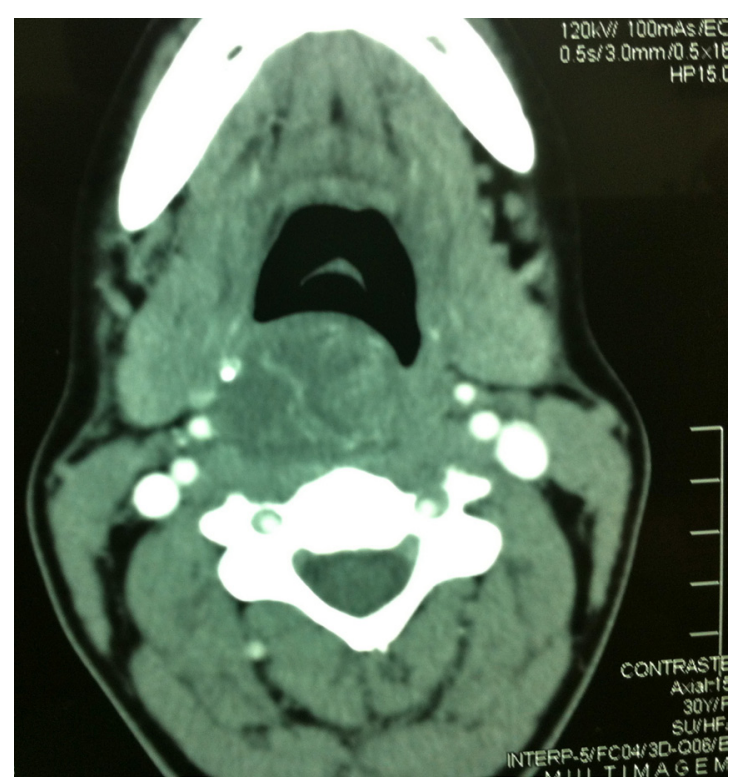

Figure 1. Computed tomography with venous contrast and axial cross-section, showing laryngeal tumor with an intimate relationship with the right-side carotid arteries. bleeding via the oral cavity, presenting hemodynamic instability, even after careful review of hemostasis and tests for intraoperative coagulation disorder. The vascular surgery team were called and requested to make an emergency assessment.

After hemodynamic stabilization, selective arteriography of the right carotid arteries was conducted, showing injury to branches of the right external carotid artery, with considerable contrast leakage (Figure 2).

Superselective catheterization was performed using an Echelon $14{ }^{\circledR}$ microcatheter (eV3 Neurovascular, Inc.) in a coaxial system, and embolization was achieved using controlled release $2 \mathrm{~mm} \times 2 \mathrm{~mm}$ and $2.5 \mathrm{~mm} \times 2 \mathrm{~mm}$ Micrus $^{\circledR}$ microcoils (Micrus Endovascular Corporation. CA/ USA), with immediate control of bleeding (Figure 3).

The patient recovered in the intensive care unit for 24 hours without further intercurrent conditions and without requiring blood transfusion, with hemodynamic stability maintained and no further bleeding. She was discharged from hospital 48 hours after embolization. The material removed was sent for pathoanatomical assessment and histological analysis confirmed a laryngeal Schwannoma. The patient attended outpatients follow-up for 30 days with the vascular surgery team and showed no sign of relapse of bleeding, laryngeal symptoms exhibited improvement and there was no evidence of neurological damage.

\section{DISCUSSION}

Schwannomas of the larynx present as tumors with extensive vascularization and slow growth and symptomology is caused by their growth and mass

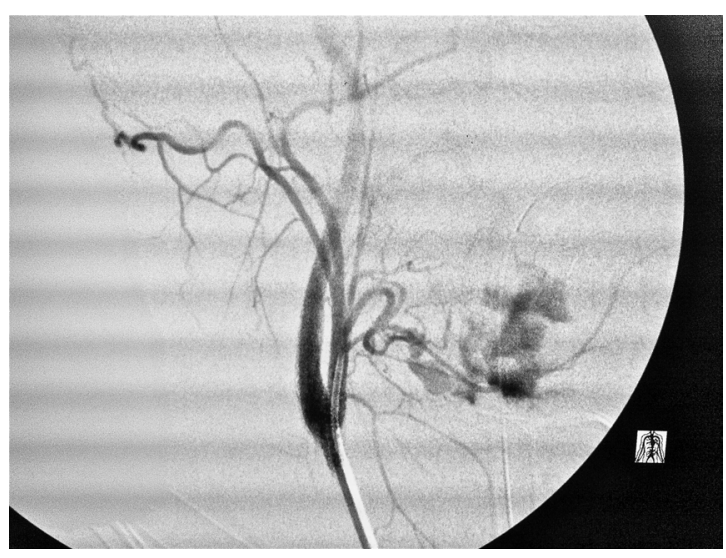

Figure 2. Selective arteriography with digital subtraction, showing contrast leaking via branches of the right external carotid artery. 


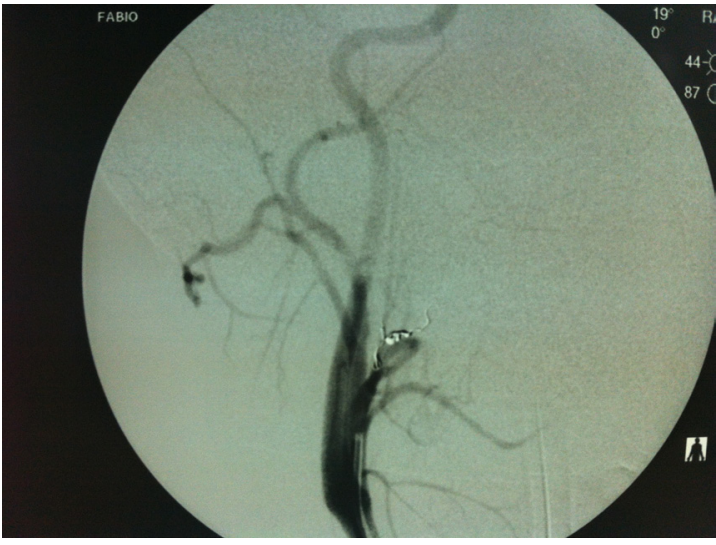

Figure 3. Control arteriography after selective embolization. No sign of contrast leakage.

effects. The treatment of choice is surgical resection and access can be intraoral, by direct laryngoscopy, or via an external approach (lateral pharyngotomy or laryngofissure $)^{8,9}$, depending on the tumor's anatomic characteristics. The transoral approach is associated with a lower incidence of recurrent paralysis of the laryngeal nerve during the postoperative period, but complete resection of the tumor can prove difficult using this approach ${ }^{4}$.

Arteriographic assessment and preoperative embolization are described for management of head and neck Schwannomas ${ }^{10}$, but no cases of embolization of a laryngeal Schwannoma, whether preoperative or postoperative, were found in the literature, probably because of the rarity of the presentation.

This paper described a rare case of a patient with a Schwannoma of the larynx who required immediate emergency embolization to control severe hemorrhage.

\section{ACKNOWLEDGEMENTS}

We are grateful to Dr. Gustavo Jorge of the otorhinolaryngology team at the Hospital São Francisco de Assis for the referral and for following the case in conjunction.

\section{REFERENCES}

1. Fini-Storchi I, Frosini P. Laryngeal neurinomas (a case report and review). ORL. 1997;59:182-5. PMid:9186976. http://dx.doi. org/10.1159/000276935
2. Palva T, Jokinem K, Karja J. Neurilemmoma (schwannoma) of the larynx. J Laryngol Otol. 1975;89:203-7. PMid:1123570. http:// dx.doi.org/10.1017/S0022215100080270

3. Phang WK, Raman R, Jayalaksmi E. Neurogenous tumour of the larynx (a case report). J Laryngol Otol. 1987;101:1209-10. PMid:3694036. http://dx.doi.org/10.1017/S0022215100103512

4. Takumida M, Taira T, Suzuki M, Yajin K, Harada Y. Neurilemmoma of the larynx (a case report). J Laryngol Otol. 1986;100:847-50. PMid:3734607. http://dx.doi.org/10.1017/S0022215100100180

5. Barnes L, Ferlito A. Soft tissue neoplasms. In: Ferlito A. Neoplasms of the larynx. Edinburgh: Churchill Livingstone; 1993. p. 277-9.

6. Supance JS, Quenelle DJ, Crissman J. Endolaryngeal neurofibromas. Otolaryngol Head Neck Surg. 1980;88:74-8. PMid:7393604.

7. Delozier HL. Intrinsic malignant schwannoma of the larynx: a case report. Ann Otol Rhinol Laryngol. 1982;91:336-8. PMid:7092059.

8. Schaeffer BT, Som PM, Biller HF, Som ML, Arnold LM. Schwannoma of the larynx: review and computed tomographic scan analysis. Head Neck Surg. 1986;8:469-72. PMid:3721890. http://dx.doi. org/10.1002/hed.2890080613

9. Whittam DE, Morris TMO. Neurilemmoma of the larynx. J Laryngol Otol. 1970;84:747-50. http://dx.doi.org/10.1017/ S0022215100072480

10. Abramowitz J, Dion JE, Jensen ME, et al. Angiographic diagnosis and management of head and neck schwannomas. AJNR. 1991;12:977984. PMid:1950934

$$
\begin{array}{r}
\text { Correspondence } \\
\text { Fabio Augusto Cypreste Oliveira } \\
\text { Av. Alphaville Flamboyant, 3900, casa } 283 \\
\text { CEP 74884527 - Goiânia (GO), Brasil } \\
\text { Fone: +55 (62) 81475111 } \\
\text { E-mail: fabioacoliveira@gmail.com }
\end{array}
$$

Author's information FACO, CESA and FLC are physicians with a Lato Sensu degree in Vascular Surgery - Angioradiology and Endovascular Surgery from Sociedade Brasileira de Angiologia e Cirurgia Vascular (SBACV), Colégio Brasileiro de Radiologia (CBR), and Associação Médica Brasileira (AMB)

WS is vascular surgeon at Angiogyn. MCRA is hematologist at Angiogyn

JCB is resident physician of infectology at Hospital das Clínicas da Universidade Federal de Goiás. MCB is resident physician of intensive care at Hospital das Clínicas da Universidade Federal de Goiás. PMS is nurse technician and surgical technician at Angiogyn.

Author's contributions Conception and design: FACO Analysis and interpretation: FACO, CESA, FLC, WS Data collection: FACO, MCRA, JCB, MCB, PMS Writing the article: FACO, MCRA, JCB, MCB,WS Critical revision of the article: FACO, CESA, FLC Final approval of the article*: FACO, CESA, FLC Statistical analysis: FACO, CESA, FLC Overall responsibility: FACO, CESA, FLC Obtained funding: None.

*All authors should have read and approved of the final version of the article submitted to I Vasc Bras. 